Relationship between Market Related Factors and

Fatma Ahmed Elsayed Ahmed Morsy

\title{
Relationship between Market Related Factors and Customer Experience in Hypermarkets in Egypt Fatma Ahmed Elsayed Ahmed Morsy
}

\section{Abstract:}

This research aims at investigating the relationship between market related factors including (atmosphere, convenience, personal interaction and customer to customer interaction) and customer experience in hypermarkets.

The findings showed that market related factors including (atmosphere, convenience, personal interaction and customer to customer interaction) significantly and positively contribute to customer experience. Additionally, atmosphere was found to be the most significant determinant of customer experience.

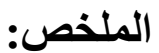

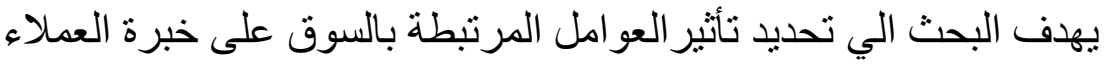

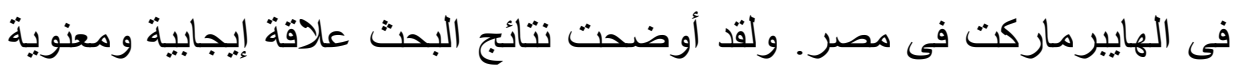
مابين العوامل المرتبطة بالسوق (المناخ العام للمتجر، ملائمة الخدمة، التهائ التفاعل

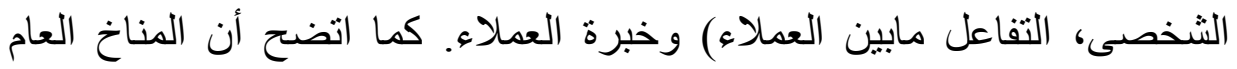

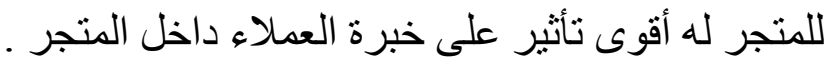


Relationship between Market Related Factors and

Fatma Ahmed Elsayed Ahmed Morsy

\section{Introduction}

Nowadays, competing in the marketplace has become increasingly difficult coupled with the similarity of the products and services offered by businesses. Besides, other factors such as advanced technology, sophisticated and demanded customers, traditional methods of offering goods and services have made firms moving beyond goods and services to focus more on customer matters (Pine and Gilmore, 1999).

According to many reports in Barnes (2002), customer relationship management failed to deliver the expected levels of value for customers and profitability for organizations (Palmer, 2010).Also, the internet allowed lower barrier of entry toward the implementation of customer relationship management (Nasution et al.,2014).

Amid all of this, contemporary customers demand not only competent services but also unique and memorable experiences that accompany the delivery of products and services. Consequently, customer experience may be a new mean of competition in markets and the successor of customer relationship management (Nasermoadeli et al., 2013; Palmer, 2010; Verhoef et al., 2009; Meyer and Schwager, 2007; Nasution et al., 2014). 
Relationship between Market Related Factors and

Fatma Ahmed Elsayed Ahmed Morsy

Since then; customer experience has emerged as a holistic perspective and a multidimensional concept comprising customer sensorial, emotional, cognitive, physical and social responses (Verhoef et al., 2009; Brakus et al., 2009).

Despite the growing recognition of the importance of customer experience, limited contributions from scholars to capture the true meaning of the concept has been made. Palmer (2010) has observed that scholars face little consensus on customer experience definition and its measures.

In fact, the concept of experience has applied in different contexts such as transport, travel, restaurants, tourism. Nevertheless, identifying the determinants of customer experience has been particularly challenging due to the lack of empirical research chiefly in hypermarket sector which is regarded as a retailing format.

Thus, this research focuses on customer experience and its determinants so as to enable retailers to apply that new approach and eliminate phenomena of lowering prices as means of competition.

\section{Literature Review and Hypotheses Development}

According to conceptual framework introduced (by Verhoef et al, 2009; Farias et al., 2014), store atmosphere is an 
Relationship between Market Related Factors and

Fatma Ahmed Elsayed Ahmed Morsy

essential determinant in order to provide superior experience. In a study focusing on music impact, Jain and Bagdare (2009) find that music acts a powerful sensory stimulus affecting customer experience at various levels (cognitive, emotional and behavioral). Further, Pareigis, Edvardsson and Enquist, (2011) confirmed that physical environment influences service experience either positively or negatively through the noise level, temperature and cleanliness of the environment.

Based on these findings, the following hypothesis is derived:

\section{H1a: Atmosphere is significantly and positively contributed to customer experience.}

In a study carried out in a banking context by Garg et al., (2014), it was found that out of 11 factors affecting customer experience, convenience is considered as the most significant among all other factors. Other researchers have also reported the importance of convenience as one of the essential elements of the shopping experience. For instance, Srivastava and Kaul (2014) also proved that location, utilities and entertainment are considered as descriptors of convenience and perceived convenience leading to favorable customer experience and in turn leading to customer satisfaction. From these findings, the following hypothesis is derived:

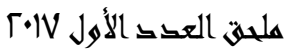


Relationship between Market Related Factors and

Fatma Ahmed Elsayed Ahmed Morsy

H1b: Convenience is significantly and positively contributed to customer experience.

Interactions during service delivery have been shown to have a significant impact on customer experience. The importance of employee-customer interactions was highlighted in the tourism sector (Cetin et al., 2014), in the universities (Garg et al., 2014) as well as within the retail sector (Bagdare, 2012).From these findings, the following hypothesis are derived:

\section{H1c: Personal interaction is significantly and positively contributed to customer experience.}

Brotoco et al., (2012) results showed that evaluations of customer experience that simply emphasizes the aspects of a firm performance (e.g service quality) may be incomplete in contexts where customer shares the service facility. Nasermoadeli et al., (2013) also support the concept of customer experience creation model by Verhoef et al., 2009. They found a significant relationship between social interaction and sensory and emotional experience. From these findings, the following hypothesis is derived:

H1d: Customer to customer interaction is significantly and positively contributed to customer experience. 
Relationship between Market Related Factors and

Fatma Ahmed Elsayed Ahmed Morsy

\section{The Research Methods \\ 3.1 Sample Selection}

The target population of the present research is all shopping customers in three selected hypermarkets (Carrefour, spinney's and hyper one) in Egypt.

A non-probability quota sample design is utilized because the population is heterogeneous, exceed millions and no sampling frame is available. Thus, the sample size equals to 384 . Approximately, the sample size of 384 is obtained by reviewing statistical tables in (Saunders et al., 2009; p.219; Collis and Hussey, 2009; p.211).

\subsection{Data collection method:}

A self-administered structured questionnaire is utilized to gather data from shoppers in hypermarkets.

\subsubsection{Questionnaire design}

The questionnaire was designed in English language taking into consideration the data required and scale items utilized in testing hypotheses. Since the target group study is Egyptian customers, the questionnaire was translated into Arabic and was reviewed by peers and marketing professors.

The questionnaire of this research was mostly composed of questions of interval scale. All statement in the questionnaire with an interval scale had five points on likert scale, where respondents indicate their agreement or disagreement. 
Relationship between Market Related Factors and

Fatma Ahmed Elsayed Ahmed Morsy

\subsubsection{Data Collection process}

For this research, self-administered questionnaire is chosen. Through, self-administered questionnaire, respondents fill in the questionnaire without any intervention from the researcher. Data was collected in Arabic language of measuring tool to enable respondents to comprehend all questions. The researcher hands the questionnaire out in a printed form (hard copy) on customers from different demographic profiles (age, gender) and from different hypermarkets (Carrefour, spinney's and hyper one). The data collection process began on November 1 th and ended on January $28^{\text {th }}, 2016$. Further, 480 printed questionnaires were distributed to customers, only (384) questionnaires were returned complete and valid for the analysis.

\section{Data analysis Techniques}

This section will introduce the outline of the statistical techniques utilized to analyze the gathered data throughout this research. The following is a brief for each technique and test adopted in this research.

1- Descriptive statistics is utilized to describe the basic features of sample data and provide simple summaries about the sample and measures.

2- Reliability and validity of the analysis

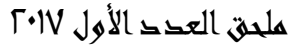




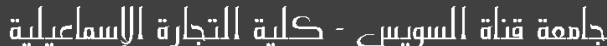

Relationship between Market Related Factors and

Fatma Ahmed Elsayed Ahmed Morsy

- Cronbach's alpha is conducted to test the reliability of all multi-item scales.

- Confirmatory factor analysis is employed to test the validity of used scales.

3- Testing hypotheses through multiple regression analysis.

\subsection{Descriptive statistics of the research variables}

\section{Table 4.1 Descriptive Statistics}

\begin{tabular}{||c|c|c||}
\hline Variables & Mean & SD \\
\hline Atmosphere & 3.857 & .6082 \\
\hline Convenience & 3.693 & .5980 \\
\hline Personal interaction & 3.810 & .6206 \\
\hline Customer to customer interaction & 3.478 & .7086 \\
\hline Customer experience & 3.632 & .7103 \\
\hline A.Sensory experience & 3.856 & .7319 \\
\hline B.Affective experience & 3.793 & 07732 \\
\hline C.Intellectual experience & 3.610 & .7767 \\
\hline D.Physical experience & 3.427 & 1.131 \\
\hline E. Social experience & 3.472 & .9452 \\
\hline
\end{tabular}

Note: $\mathrm{SD}=$ standard deviation 
Relationship between Market Related Factors and

Fatma Ahmed Elsayed Ahmed Morsy

- For market related factors, the most important is atmosphere itself, with mean of (3.857) followed by personal interaction (3.810), convenience (3.693) and customer to customer interaction (3.478) respectively. The ratings revealed that the respondents believed that presence of several combinations of atmospheric cues (e.g. design, decorations, color, lighting and music) are pleasant. Interactions with hypermarket employees are viewed as important for customers. They agreed in terms of employees are friendly, helpful, neat and well dressed and give them sense of trust. Further, the least important factor was customer to customer interactions.

- Finally, the mean of customer experience dimensions range from (3.856) to (3.427) according to the 5-point Likert scale of measurement. Thus, the researcher concludes that there is agree direction to customer experience construct which indicates that respondents tended to have positive experience with their hypermarket. In relation to customer experience, it is noted that the sensory experience is the most important dimension with a highest mean (3.856) and low standard deviation (.7319).

\subsection{Reliability Analysis}

In order to secure internal consistency reliability that reflects whether items of the questionnaire are reliable and 
Relationship between Market Related Factors and

Fatma Ahmed Elsayed Ahmed Morsy

consequential or not, Cronbach's alpha technique was used using SPSS software for all scale items. The alpha coefficient $(\alpha)$ has a value from (0) no internal reliability to (1) perfect reliability and hence the closer alpha coefficient is to 1 , the higher internal consistency reliability and the better measuring instrument.

Table 4.2. Reliability and intrinsic validity for research variables

\begin{tabular}{|c|c|c|c|c|}
\hline No & Construct & $\begin{array}{l}\text { No of } \\
\text { items }\end{array}$ & $\begin{array}{c}\text { Reliability } \\
\text { coefficient } \\
\alpha\end{array}$ & $\begin{array}{l}\text { Intrinsic } \\
\text { Validity }\end{array}$ \\
\hline 1 & Atmosphere & 9 & .816 & .903 \\
\hline 2 & Convenience & 9 & .805 & .897 \\
\hline 3 & $\begin{array}{c}\text { Personal } \\
\text { interaction }\end{array}$ & 8 & .858 & .926 \\
\hline 4 & $\begin{array}{l}\text { Customer to } \\
\text { customer } \\
\text { interaction }\end{array}$ & 6 & .830 & .911 \\
\hline 5 & $\begin{array}{l}\text { Customer } \\
\text { experience }\end{array}$ & 17 & .919 & .958 \\
\hline & Total & 64 & .956 & .977 \\
\hline
\end{tabular}


Relationship between Market Related Factors and

Fatma Ahmed Elsayed Ahmed Morsy

According to table (4.2), the reliability coefficient and intrinsic validity for research variables are (.956) and (.977) respectively. Since Cronbach 's alpha of scale is closer to 1 which represent higher internal consistency reliability. The most three constructs with highly reliability coefficient are customer experience, personal interaction and customer to customer interactions with reliability coefficient (.919), (.858) and (.830).

4.3. Confirmatory Factor Analysis:

Table 4.3.Confirmatory Factor Analysis by standardized and unstandardized regression weights

\begin{tabular}{|c|c|c|c|c|c|c|c|}
\hline \multicolumn{3}{|r|}{ Path } & \multirow{2}{*}{ 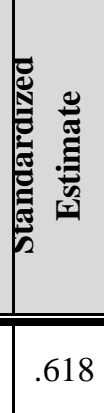 } & \multirow{2}{*}{ 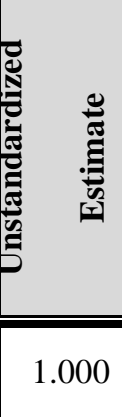 } & \multirow{2}{*}{$\frac{5}{\dot{\infty}}$} & \multirow{2}{*}{$\mid$} & \multirow{2}{*}{ 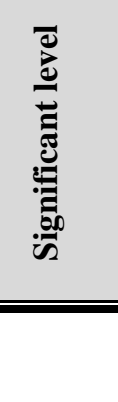 } \\
\hline $\begin{array}{c}\mathrm{Q} 2 \\
1\end{array}$ & 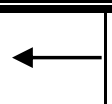 & Atmosphere & & & & & \\
\hline $\begin{array}{c}\text { Q2 } \\
0\end{array}$ & & Atmosphere & .562 & 1.057 & .114 & 9.234 & $.001 * * *$ \\
\hline $\begin{array}{c}\text { Q1 } \\
9\end{array}$ & & Atmosphere & .585 & .977 & .102 & 9.543 & $.001 * * *$ \\
\hline $\begin{array}{c}\mathrm{Q} 1 \\
5\end{array}$ & & Atmosphere & .571 & 1.026 & .110 & 9.292 & $.001 * * *$ \\
\hline $\begin{array}{c}\mathrm{Q} 1 \\
4\end{array}$ & & Atmosphere & .775 & 1.497 & .128 & 11.719 & $.001 * * *$ \\
\hline
\end{tabular}


Relationship between Market Related Factors and

Fatma Ahmed Elsayed Ahmed Morsy

\begin{tabular}{|c|c|c|c|c|c|c|c|}
\hline & & Path & 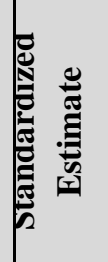 & 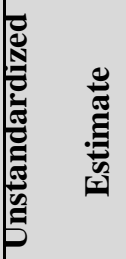 & 芴 & 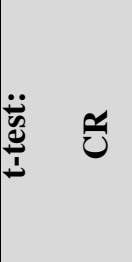 & 离 \\
\hline $\begin{array}{c}\text { Q1 } \\
3\end{array}$ & & Atmosphere & .627 & 1.068 & .107 & 10.018 & $.001 * * *$ \\
\hline $\begin{array}{c}\text { Q3 } \\
0\end{array}$ & & Convenience & .634 & .966 & .089 & 10.828 & $.001 * * *$ \\
\hline $\begin{array}{c}\text { Q2 } \\
9\end{array}$ & & Convenience & .762 & 1.063 & .084 & 12.598 & $.001 * * *$ \\
\hline $\begin{array}{c}\text { Q2 } \\
8\end{array}$ & & Convenience & .707 & 1.111 & .094 & 11.869 & $.001 * * *$ \\
\hline $\begin{array}{c}\text { Q2 } \\
7\end{array}$ & & Convenience & .603 & .795 & .084 & 9.449 & $.001 * * *$ \\
\hline $\begin{array}{c}\text { Q3 } \\
1\end{array}$ & & Convenience & .674 & 1.000 & & & \\
\hline $\begin{array}{c}\text { Q3 } \\
2\end{array}$ & & Personal interaction & .649 & 1.000 & & & \\
\hline $\begin{array}{c}\text { Q3 } \\
3\end{array}$ & & Personal interaction & .613 & 1.023 & .096 & 10.607 & $.001 * * *$ \\
\hline $\begin{array}{c}\text { Q3 } \\
4\end{array}$ & & Personal interaction & .644 & 1.265 & .114 & 11.068 & $.001 * * *$ \\
\hline $\begin{array}{c}\text { Q3 } \\
5 \\
\end{array}$ & & Personal interaction & .683 & 1.364 & .117 & 11.637 & $.001 * * *$ \\
\hline $\begin{array}{c}\text { Q3 } \\
6\end{array}$ & & Personal interaction & .655 & 1.257 & .112 & 11.229 & $.001 * * *$ \\
\hline $\begin{array}{c}\text { Q3 } \\
7\end{array}$ & & Personal interaction & .706 & 1.142 & .096 & 11.949 & $.001 * * *$ \\
\hline $\begin{array}{c}\text { Q3 } \\
8\end{array}$ & & Personal interaction & .683 & 1.229 & .106 & 11.632 & $.001 * * *$ \\
\hline $\mathrm{Q} 4$ & $\longleftarrow$ & Personal interaction & .647 & 1.186 & .107 & 11.117 & $.001 * * *$ \\
\hline
\end{tabular}


Relationship between Market Related Factors and

Fatma Ahmed Elsayed Ahmed Morsy

\begin{tabular}{|c|c|c|c|c|c|c|c|}
\hline & & Path & 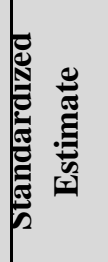 & 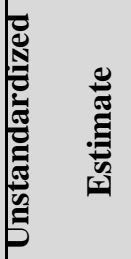 & 芴 & 苞 & 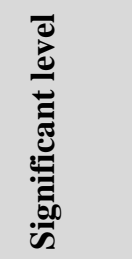 \\
\hline \multicolumn{8}{|l|}{0} \\
\hline $\begin{array}{c}\text { Q4 } \\
2\end{array}$ & 4 & $\mathrm{C} 2 \mathrm{C}$ interaction & .626 & 1.000 & & & \\
\hline $\begin{array}{c}\text { Q4 } \\
3\end{array}$ & 4 & $\mathrm{C} 2 \mathrm{C}$ interaction & .662 & .985 & .093 & 10.632 & $.001 * * *$ \\
\hline $\begin{array}{c}\text { Q4 } \\
4\end{array}$ & & $\mathrm{C} 2 \mathrm{C}$ interaction & .733 & 1.068 & .093 & 11.471 & $.001 * * *$ \\
\hline $\begin{array}{c}4 \\
5\end{array}$ & & $\mathrm{C} 2 \mathrm{C}$ interaction & .648 & .836 & .080 & 10.466 & $.001 * * *$ \\
\hline $\begin{array}{c}\text { Q4 } \\
6\end{array}$ & & $\mathrm{C} 2 \mathrm{C}$ interaction & .677 & .979 & .090 & 10.819 & $.001 * * *$ \\
\hline $\begin{array}{c}\text { Q4 } \\
7\end{array}$ & & $\mathrm{C} 2 \mathrm{C}$ interaction & .692 & .931 & .085 & 11.000 & $.001 * * *$ \\
\hline $\begin{array}{c}\text { Q4 } \\
9\end{array}$ & & Customer experience & .600 & 1.000 & & & \\
\hline $\begin{array}{c}\text { Q5 } \\
0\end{array}$ & & Customer experience & .665 & 1.197 & .111 & 10.771 & $.001 * * *$ \\
\hline $\begin{array}{c}\text { Q5 } \\
1\end{array}$ & & Customer experience & .666 & 1.184 & .110 & 10.775 & $.001 * * *$ \\
\hline $\begin{array}{c}\text { Q5 } \\
2\end{array}$ & & Customer experience & .664 & 1.440 & .134 & 10.752 & $.001 * * *$ \\
\hline $\begin{array}{c}\text { Q5 } \\
3\end{array}$ & & Customer experience & .739 & 1.390 & .120 & 11.617 & $.001 * * *$ \\
\hline $\begin{array}{c}\text { Q5 } \\
4\end{array}$ & & Customer experience & .745 & 1.354 & .116 & 11.675 & $.001 * * *$ \\
\hline $\begin{array}{c}\mathrm{Q} 5 \\
5\end{array}$ & & Customer experience & .775 & 1.554 & .130 & 11.997 & $.001 * * *$ \\
\hline
\end{tabular}


Relationship between Market Related Factors and

Fatma Ahmed Elsayed Ahmed Morsy

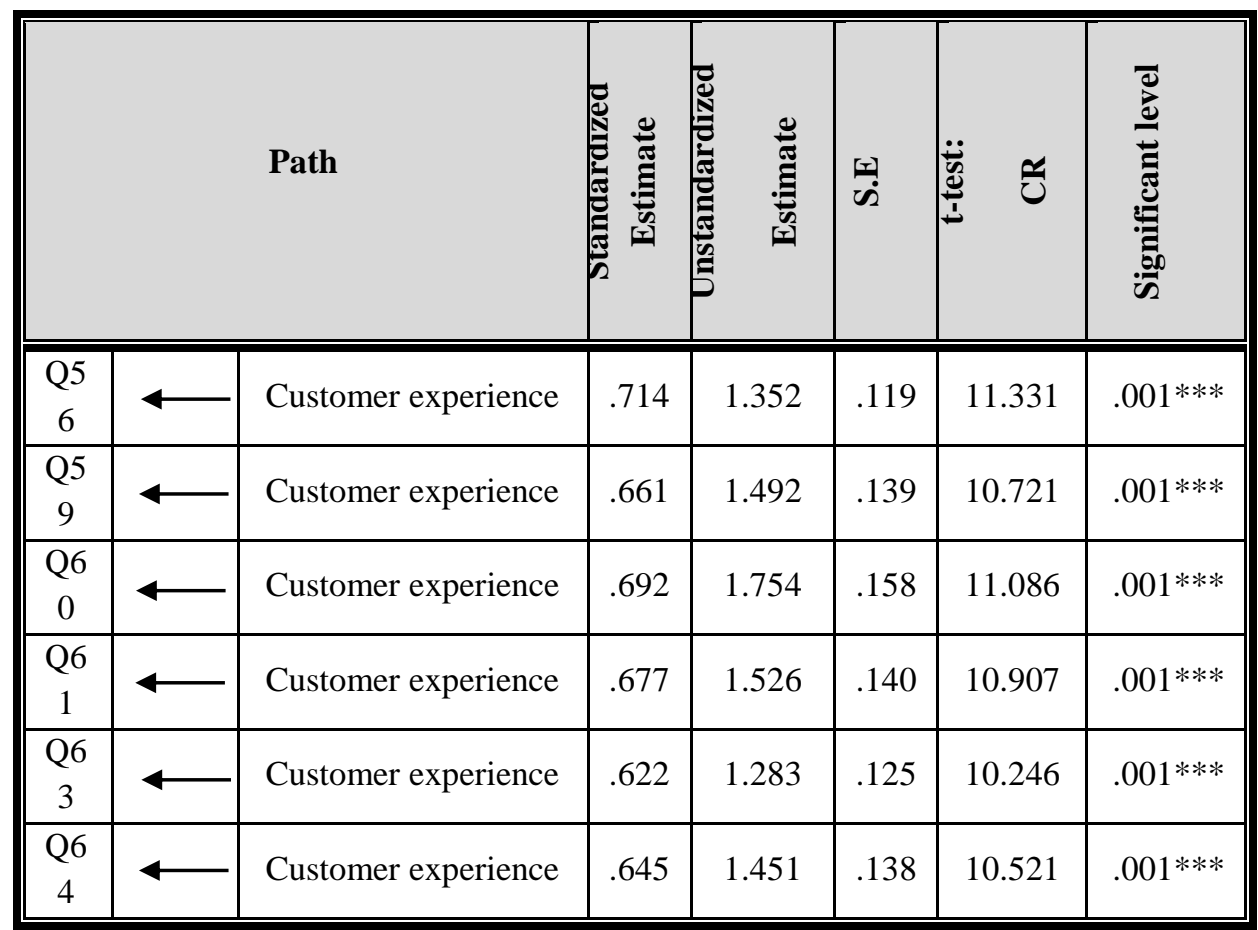

According to table 4.3, the researcher can conclude the following;

- All standardized regression weights (factor loading) are greater or equal (.50) which means that all measured variables are statistically significant, i.e. the measured variables represent constructs

- t-test for all measured variables is significant at a level of significance less than (.001) which indicates that product 


\section{جاجمة قألة السويس - كلية التجارة إلسماعيلية}

Relationship between Market Related Factors and

Fatma Ahmed Elsayed Ahmed Morsy

relevant factors and market relevant factors are determinants of customer experience.

- Squared multiple correlations, i.e. average variance extracted for all constructs have close to fit cut- off values.

\section{The Goodness of Fit of the (Final CFA) Model}

Table 4.4 the goodness of fit indices in the final confirmatory indices

\begin{tabular}{|c|c|}
\hline Indices & Value \\
\hline \hline Chi- Square & 4115.407 \\
\hline Degree of Freedom (DF) & 915 \\
\hline Level of Significance (P) & .001 \\
\hline Normed Chi-Square & 4.498 \\
\hline Root Mean Square Residual (RMR)<.10 & .067 \\
\hline Goodness of Fit Index (GFI) & .648 \\
\hline Adjusted Goodness of Fit Index (AGFI) & .602 \\
\hline Normed Fit Index (NFI) & .617 \\
\hline Relative Fit Index (RFI) & .586 \\
\hline Incremental Fit Index (IFI) & .674 \\
\hline Tucker Lewis Index (TLI) & .645 \\
\hline
\end{tabular}


Relationship between Market Related Factors and

Fatma Ahmed Elsayed Ahmed Morsy

\begin{tabular}{|c|c|}
\hline Comparative Fit Index (CFI) & .672 \\
\hline Root Mean Square Residual Approximation \\
$($ RMSEA) $<0.10$ & .096 \\
\hline The average variance extracted & 0.427 \\
\hline
\end{tabular}

- As highlighted in table 4.4, the researcher demonstrates that all the goodness of fit tests of the model displayed significant results, where the indicators are at acceptable limits to cutoff values. Thus, there is possibility of matching the actual form of the model estimated. In addition, the values of Root Mean Square Residual (RMR) and Root Mean Square Residual approximation (RMSEA) are less than .10.

- Furthermore, the mean variance extracted for all latent constructs is .427 which indicates that there is adequate convergent validity. AVEs of all scales turned to be at acceptable limits to cut-off values. As shown, average variance extracted for the constructs of atmosphere, convenience, personal interaction, customer to customer interaction and customer experience are as follow (.4),(.460), (.437),(.454),(.467).In sum, the hypothesized model shows satisfactory fit indices that are about to reach the desired range, thus the model is acceptable. 
Relationship between Market Related Factors and

Fatma Ahmed Elsayed Ahmed Morsy

\subsection{Multiple Regression analysis}

Regression analysis was carried out to analyze the associative relationships between market relevant factors and customer experience.

\section{Table 4.5 Multiple Linear Regression Analysis for Hypothesis Testing}

\begin{tabular}{||c|c|c|c|c|c|c|c|c||}
\hline \multirow{2}{*}{ No } & \multirow{2}{*}{$\begin{array}{c}\text { Independent } \\
\text { variables }\end{array}$} & \multirow{2}{*}{$\begin{array}{c}\text { Estimated } \\
\text { coefficient }\end{array}$} & \multicolumn{2}{|c|}{ t-test } & \multicolumn{2}{|c|}{ f-test } & \multirow{2}{*}{$\mathbf{R}^{2}$} & \multirow{2}{*}{ VIF } \\
\cline { 4 - 8 } & & Value & Sig. & Value & Sig. & $\%$ & \\
\hline \hline $\mathbf{1}$ & Atmosphere & .176 & 9.672 & $0.001^{* * *}$ & & & & 2.237 \\
\hline $\mathbf{2}$ & Convenience & .148 & 7.354 & $0.001^{* * *}$ & & & & 2.625 \\
\hline $\mathbf{3}$ & $\begin{array}{c}\text { Personal } \\
\text { interaction }\end{array}$ & .138 & 8.628 & $0.001^{* * *}$ & & & & 3.157 \\
\hline $\mathbf{4}$ & $\begin{array}{c}\text { C2C } \\
\text { interaction }\end{array}$ & .071 & 4.669 & $0.001^{* * *}$ & & & & 2.099 \\
\hline
\end{tabular}

* Parameter is significant at the .05

****arameter is significant at the .001

As indicated by table 4.5 , statistics interpretation can be summarized as follows;

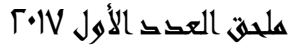


Relationship between Market Related Factors and

Fatma Ahmed Elsayed Ahmed Morsy

- F-test

As shown in previous table, the value of $\mathrm{F}$ is equal 617.036 with significant at .001 level. This reveals that independent variables that were accepted in the model have been influenced on customer experience

- t-test

t-test is used to determine the significant values of each independent variable in the regression model. Testing for significance of the independent variables indicates a high level of significance at .001 level .Thus, all marketing determinants are considered worthy for improving customer experience.

\section{- Regression Equation}

Customer experience $=.138+.176$ atmosphere +.148 convenience+.138 personal interaction+ .071 customer to customer interaction

\section{Summary and Conclusion}

The research aimed to explore the major determinants influencing customer experience in the hypermarket sector in Egypt.

In order to pursue this objective, a mixed research design was adopted. Firstly, a qualitative exploratory study was carried out, then a conceptual framework that investigates the relationship between market related factors and customer experience was proposed. Secondly, this framework was

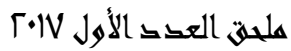


Relationship between Market Related Factors and

Fatma Ahmed Elsayed Ahmed Morsy

tested by means of a survey of Egyptian shoppers in the hypermarkets.

The research is based not on probability sampling but on "Quota sampling". Utilizing the chosen sample design, questionnaires were administered at three different hypermarkets in Egypt (Carrefour, Spinneys, hyper one). A total of 480 questionnaires were distributed on shoppers in theses hypermarkets. Of the total 480 customer chosen, 384 responded to the questionnaire yielding response rate $(80 \%)$. Thereafter, the questionnaires were utilized for data analysis. Reliability and validity tests are then employed in order to secure the research quality. In order to test the proposed research hypotheses, the researcher conducted a multiple regression analysis.

The main research findings revealed that atmosphere is regarded the strongest predictor of customer experience. Also, It is clear that the offering aspects of convenience in the hypermarkets (e.g.the availability of parking, late operating hours, the availability of proper information, proximity of location as well as the ease and speed of shopping process) can actively shape a superior customer experience.

Besides, the interactions between the employees and customers have a positive impact on customer experience. The 
Relationship between Market Related Factors and

Fatma Ahmed Elsayed Ahmed Morsy

findings of this research also clarified that customer to customer interaction has the least significant weight on shaping customer experience. This result may be due to the lack of customers' awareness of how other shoppers can affect their own behavior and experience on one side. They may not notice the other shoppers until the interaction action impinge on their service experience either positively or negatively on the other side.

\section{$\underline{\text { 6.Recommendations }}$}

This research could open new avenues for future research stream of customer experience in a service setting. Thus, various suggestions are recommended as follow:

1) This study focused on customer experience in hypermarket sector. It would be interesting to explore marketing determinants of customer experience in other contexts in Egypt (airline, tourism, restaurants, mobile services, transportation).

2) Future studies should be carried to investigate the consequences of customer experience .It would be valuable to study the influence of customer experience on outcome variables such as customer satisfaction, 
Relationship between Market Related Factors and

Fatma Ahmed Elsayed Ahmed Morsy

customer loyalty, customer retention, profitability and others.

3) Other variables can be added to the study model such as retail brand, promotion, advertising, word of mouth, technology, fast-checkout as well as consumer demographics (e.g. gender, age). A number of researchers argued that there is link between customer experience and these variables. For instance, retail brand and past customer experience are proposed to be vital determinants of customer experience (Verhoef et al., 2009).Besides, Grewal et al., (2009) argued that the firmcontrolled factors such as promotion can affect customer experience in a retail setting. Other factors can influence customer experience such as advertising and word of mouth as claimed by (Ismail, 2010) as well as fast checkout and consumer demographics (e.g. Mitta and Gupta, 2012) and technology (Cetin et al., 2014).

4) The research depends on scale items from prior literature in order to measure customer experience. Bearing in mind that there is lack of a universally accepted scale that reflects customer experience dimensions .Therefore; future research should be accomplished to develop alternative measuring scale for customer experience. 
Relationship between Market Related Factors and

Fatma Ahmed Elsayed Ahmed Morsy

5) Due to the restrictions of generalization, future research can focus on adopting probability sampling technique for more validation.

6) Longitudinal research design would be more recommended to gain more reliable findings.

7) Future research can extend this study by focusing on the company side and grasp a deeper understanding for customer experience design.

8) It is considered meaningful to replicate this study in other countries to provide a cross cultural comparison and ensure whether the model still provides the same results. 
Relationship between Market Related Factors and

Fatma Ahmed Elsayed Ahmed Morsy

\section{References:}

Bagdare, S. (2012). Managing Employee Effectiveness for Retail Customer Experience. Asia Pacific Marketing Review, 1(1), 98-106. Barnes, J. G. (2001). Secrets of customer relationship management: It's all about how you make them feel. McGraw-Hill Companies.

Brakus, J. (2001). A theory of consumer experiences. Unpublished doctoral dissertation, Columbia University.

Brocato, E. D., Voorhees, C. M., \& Baker, J. (2012). Understanding the influence of cues from other customers in the service experience: A scale development and validation. Journal of Retailing, 88(3), 384-398.

Cetin, G., \& Dincer, F. I. (2014). Influence of customer experience on loyalty and word-of-mouth in hospitality operations. Anatolia, 25(2), 181-194.

Collis, J., \& Hussey, R. (2009). Business research: a practical guide for undergraduate and postgraduatestudents, 3rd edition, Palgrave Macmillan.

Farias, S. A., Aguiar, E. C., \& Melo, F. V. S. (2014). Store atmospherics and experiential marketing: A conceptual framework and research propositions for an extraordinary customer experience. International Business Research, 7(2), 87.

Garg, R., Rahman, Z., \& Qureshi, M. N. (2014). Measuring customer experience in banks: scale development and validation. Journal of Modelling in Management, 9(1), 87-117.

Meyer, C., \& Schwager, A. (2007). Customer Experience. Harvard business review, 1-11

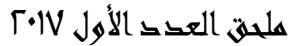


Relationship between Market Related Factors and

Fatma Ahmed Elsayed Ahmed Morsy

Nasermoadeli, A., Ling, K. C., \& Severi, E. (2013). Exploring the Relationship between Social Environment and Customer Experience. Asian Social Science,9(1), 130.

Nasution, R. A., Sembada, A. Y., Miliani, L., Resti, N. D., \& Prawono, D. A. (2014). The customer experience framework as baseline for strategy and implementation in services marketing. Procedia-Social and Behavioral Sciences, 148, 254-261.

Palmer, A. (2010). Customer experience management: a critical review of an emerging idea. Journal of Services marketing, 24(3), 196-208.

Pareigis, J., Edvardsson, B., \& Enquist, B. (2011). Exploring the role of the service environment in forming customer's service experience. International Journal of Quality and Service Sciences, 3(1), 110-124.

Pine, B.J. and Gilmore, J.H. (1999), The Experience Economy, Harvard Business School Press, Boston, MA.

Saunders, M, Lewis, P., Thornhill, A. (2009). Research Methods for Business Students.fifth edition, Pearson Education, Edinburgh.

Srivastava, M., \& Kaul, D. (2014). Social interaction, convenience and customer satisfaction: The mediating effect of customer experience. Journal of Retailing and Consumer Services, 21(6), 1028-1037.

Verhoef, P. C., Lemon, K. N., Parasuraman, A., Roggeveen, A., Tsiros, M., \& Schlesinger, L. A. (2009). Customer experience creation: Determinants, dynamics and management strategies. Journal of Retailing, 85(1), 31-41.

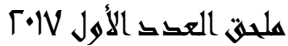

